МЕНЕДЖМЕНТ

UDC 621.316

O. P. Kosenko, Doctor of Economic Sciences, Professor,

T. O. Kobielieva, Candidate of Economic Sciences, Associate Professor, N. P. Tkachova, Candidate of Economic Sciences, Associate Professor

\section{FORECASTING INDUSTRY PARK ELECTRICAL PRODUCTS}

Urgency of the research. The predictive value of the industry Park electrical products largely determines the market prospects of the production and sales of electrotechnical companies.

Target setting. Market characteristics electrical products are largely connected with the current and future needs, the dimensions of which are determined by the fleet of products in service.

Actual scientific researches and issues analysis. Problems of forecasting industry Park of various types of equipment were considered by such scientists as llyashenko S. N. [4], Kozicki D. [5], Pererva P. G. [6; 7], Plotnikov V. A. [8], Poberesna N. I. [9], Pogorelov N. I. [10] etc.

Uninvestigated parts of general matters defining. Almost no methodological developments in forecasting Park products which do not have independent technological applications, which significantly complicates the formation of market characteristics of the production program of industrial enterprises.

The research objective. The purpose of this article is to develop methodological principles of forecasting industry Park electrical products.

The statement of basic materials. To predict the size of the industry Park electrical products is proposed by addressing two interrelated challenges: a) prediction of old machinery, automated operation which provide these products; b) determining the growth index of the level of mechanization and automation of the basic types of equipment, i.e. the change in the number of different types of products (ratios of applicability) per piece of equipment. On the basis of statistical processing of variation coefficients of the applicability of the products over a long period of mathematical models for certain types of products, allowing to predict the coefficients of applicability.

Conclusions. The proposals of the authors on forecasting industry Park of products on the basis of factors of applicability eliminate labor-intensive method of immediate (direct) account. The research results can be used to form normative and reference materials for marketing research.
Удк 621.316

О. П. Косенко, д. э. н. профрессор

Т. А. Кобелева, к. э. Н., доцент,

Н. П. Ткачева, к. э. Н., доцент

\section{ПРОГНОЗИРОВАНИЕ ОТРАСЛЕВОГО ПАРКА ЭЛЕКТРОТЕХНИЧЕСКИХ ИЗДЕЛИЙ}

Актуальность темы исследования. Прогнозное значение отраслевого парка электротехнических изделий во многом определяет рыночные перспективы производства и сбыта продукции электротехнических предприятий.

Постановка проблемы. Рыночные характеристики электротехнической продукции во многом связаны с текущими и перспективными потребностями в ней, размеры которых определяются парком изделий, находящихся в эксплуатации.

Анализ последних исследований и публикаций. Проблемы прогнозирования отраслевого парка различных видов оборудования рассматривали такие ученые, как Ильяшенко С. Н. [4], Коциски Д. [5], Перерва П. Г. [6; 7], Плотников В.А. [8], Побережна Н. И. [9], Погорелов Н. И [10] и др.

Нерешенные проблемы. Практически отсутствуют методические разработки по прогнозирования парка изделий, не имеющих самостоятельного технологического назначения, что существенно усложняет фрормирование рыночных характеристик производственной программы промышленных предприятий.

Постановка задачи. Целью статьи является разработка методических положений прогнозирования отраслевого парка электротехнических изделий.

Основные результаты исследования. Прогнозировать размеры отраслевого парка электротехнических изделий предлагается путем решения двух взаимосвязанных задач: а) прогнозирование парка технологического оборудования, автоматизированную работу которого обеспечивают эти изделия; b) определение индекса роста уровня механизации и автоматизации основных видов оборудования, т.е. изменение количества различных видов изделий (коэсрфиициентов применяемости) в расчете на единицу оборудования. На основе статистической обработки динамики изменения коэфффициентов применяемости изделий за длительный период предложены математические модели по отдельным видам изделий, позволяющие прогнозировать коэфффициенты применяемости.

Выводы. Предложения авторов по прогнозированию отраслевого парка изделий на основе коэфффициентов применяемости позволяют отказаться от трудоемкого метода непосредственного (прямого) счета. Результаты 


\section{МЕНЕДЖМЕНТ}

\begin{tabular}{|c|c|}
\hline & $\begin{array}{l}\text { исследований могут быть использованы для } \\
\text { формирования нормативно-справочных материалов } \\
\text { для маркетинговых исследований. }\end{array}$ \\
\hline $\begin{array}{l}\text { Keywords: electrical products; forecasting; industrial } \\
\text { Park; technological equipment; engineering. }\end{array}$ & $\begin{array}{l}\text { Ключевые слова: электротехнические изделия; } \\
\text { прогнозирование; отраслевой парк; технологическое } \\
\text { оборудование; машиностроение. }\end{array}$ \\
\hline
\end{tabular}

DOI: 10.25140/2410-9576-2017-2-4(12)-106-111 оборудование; машиностроение.

Urgency of the research. Scientific and technical progress in all sectors of our economy involves the development of electrification, mechanization and automation of technological processes increases the demand for electrotechnical products (ETP) [1]. Only in the last 25 years, the production of electrical products increased in the half, with significantly lower growth in industrial production over the same period [2;3]. The predictive value of the industry Park electrical products largely determines the market prospects of the production and sales of electrotechnical companies. Its value lies in the basis of marketing programs of manufacturers products.

Target setting. Methodological approaches to the identification of the need and demand ETP to create strategic plans for their production is impossible without predictive values of the Park of electrical products, which characterizes the actual level of consumption in various industries. In this regard, the development of scientifically-methodical bases of forecasting of the Park electrotechnical products represent an important and urgent task.

Actual scientific researches and issues analysis. Problems of forecasting industry Park of various types of equipment were considered by such scientists as llyashenko S. N. [4], Kozicki D. [5], Pererva P. G. [6; 7], Plotnikov V. A. [8], Poberesna N. I. [9], Pogorelov N. I. [10] etc. the analysis of existing publications showed that most of the proposals and recommendations of researchers to predict industry Park equipment offer expert assessments. These methods have a low accuracy and are in need of development and improvement.

Uninvestigated parts of general matters defining. The conducted research allows to make a conclusion that currently there is no single universally accepted methods of predicting industry Park of technological equipment. Attempts to create a methodology for determining the prospective value of the industry Park of equipment for separate processing groups [11].

The existing methodological framework basically contains recommendations on forecasting industry Park of technological equipment, on which is the inventory account $[1 ; 5 ; 8]$. Almost no methodological developments in forecasting Park products which do not have independent technological purpose (bearings, lamps, contactors, motors, relays, fuses, switches, electromagnets, magnetic starters, transformers, etc.), which significantly complicates the formation of market characteristics of the production program of industrial enterprises.

The research objective. The purpose of this article is to develop methodological principles of forecasting industry Park ETP. Object of research are machine-building enterprises of the Kharkov industrial region.

The statement of basic materials. The definition of industry Park ETP at any projected period is defined as the solution of two interrelated tasks:

a) forecasting the Park's main equipment, automated operation which provide ETP;

b) determining the growth index of the level of mechanization and automation of the basic types of equipment, i.e. the change in the number of different types of ETP (the coefficients of applicability) per piece of equipment.

Forecasts Park, basic equipment, and usually involved in many sectoral institutions, research departments of large industrial corporations. Therefore, we do not see here special problems in obtaining the necessary data to predict industry Park ETP.

Much harder to address the second objective was to determine the change of the coefficients of applicability of ETP per unit of process equipment, i.e. to quantify the change in the level of automation and mechanization of technological equipment of the studied industry in future. 


\section{МЕНЕДЖМЕНТ}

The future of automatic control of machine tools and other equipment is inextricably linked to the prospects for the development of the electrical industry and its subsectors, with a direct impact on the level of automation of process equipment. Just 20-25 years ago in a classic electric circuit of the cutting machine contained two control buttons, one or two magnetic starter-fuses, which provides automated control and protection of one or two asynchronous motors. All automatics were attached to the ground screw of the machine and was on a mechanical basis. Over time electric circuit metal cutting equipment, there are additional motors that perform automatic part clamping, various other auxiliary operations. Modern metal-cutting machine installed in an average of 5-6 magnetic starters, as most relays, limit and contact switches, electromagnets, circuit breakers, pushbuttons and control stations.

Automation allows a single operator to make process control and monitoring instrumentation located on panel control. The job of the operator is much more complicated, since rapid decisionmaking associated with the direct operation operation the mode of operation requires constant psychological stress. Compliance with the technological mode when an automatic operation is much higher than in manual operation. In particular, the duration of rotation of the form, the beginning of rotation of the bucket, and other operations of the automated machine of centrifugal casting of cast iron tubes kept automation to a fraction of a second. There will be a strict sequence of operations.

Automation of any equipment entails an increase in the saturation of ETP. For example, in comparison with the centrifugal acting pipe-casting machine that has a functional push-button ignition and operation, for a similar machine with automated control requires 2 motor 11 and travel end switch, 15 relay, 3 relays, 1 command device, 1 universal switch. The total number of electrical products for the automated acting pipe-casting machine of the smallest size exceeds 100 units. Similar examples can be found on machine tools and forging equipment.

In table 1 shows the generalized data on the dynamics of the coefficients of applicability of lowvoltage equipment in General and its most characteristic representatives per one cutting machine. Their determination was conducted according to the methods discussed in the article, which was published in the last issue of the journal [12].

Table 1

Evolution of the rate of applicability of electrotechnical products in one cutting machine

\begin{tabular}{|l|c|c|c|c|c|}
\hline \multirow{2}{*}{ Main groups low-voltage apparatus } & \multicolumn{5}{|c|}{ Year of study } \\
\cline { 2 - 6 } & 1995 & 2000 & 2005 & 2010 & 2015 \\
\hline The coefficients of applicability, units/machine: & \multicolumn{5}{|l|}{} \\
\hline Gelatin & 3,85 & 4,19 & 4,61 & 5,12 & 5,45 \\
\hline Breakers & 1,39 & 1,72 & 1,98 & 2,20 & 2,49 \\
\hline Electromagnets & 0,86 & 0,78 & 0,83 & 0,72 & 0,88 \\
\hline Control buttons & 5,11 & 5,46 & 6,22 & 7,21 & 7,36 \\
\hline End-travel switches & 3,51 & 4,18 & 4,88 & 5,62 & 5,42 \\
\hline Control relay & 3,64 & 3,87 & 4,09 & 4,49 & 5,08 \\
\hline Switches & 2,18 & 2,73 & 3,02 & 3,49 & 4,11 \\
\hline Terminals connecting & 73 & 66 & 70 & 65 & 68 \\
\hline Connectors & 0,76 & 0,92 & 1,23 & 1,55 & 1,73 \\
\hline Proximity switch & 0,18 & 0,94 & 1,56 & 2,09 & 2,36 \\
\hline Fuses & 6,42 & 5,81 & 7,50 & 7,30 & 8,01 \\
\hline
\end{tabular}

Source: created by the authors

Of interest is the analysis of the dynamics of certain groups of low-voltage devices on a single machine in the retrospective period (Tab.1). In connection with the decreasing dimensions of magnetic starters eliminated the functional differences between intermediate relays and small contactors AC. 


\section{МЕНЕДЖМЕНТ}

Use as intermediate relays, small contactors, in General, needs to be estimated as a positive phenomenon, as the acquisition of equipment with equipment achieves a higher degree of unification, which greatly facilitates the operating conditions and repair ETP. Trend to replace intermediate relay small contactor is particularly evident in the leading Western European countries and their firms, such as AEG, Siemens, klöckner-möller (Germany), remote control electric (France), MTE (England). Currently, in order to control the main equipment in our country as an intermediate relay widely used small contactors. This has led to continuous growth of the coefficients of applicability of magnetic starters on one machine, despite a growing tendency to replace magnetic starters for contactless control units, which are particularly widely started to be applied in press-forging equipment, in particular in the configuration with instrument mechanical presses for large efforts. At the same time the same indicators on the control relay by the same causes do not show a pronounced upward trend.

Steadily growing number of circuit breakers that objectively causes a slight increase in the number of fuses that perform essentially the same function as circuit breakers.

Almost constant is the number of solenoids and terminals defined by the classic design of the cutting machine, and the need for additional pulling or pushing effort is provided mainly by hydraulic valves. The number of connection terminals with the passage of time may decrease due to the wider application of various kinds of connectors, which provide the blocking schemes and increase the maintainability of electrical equipment.

Although the production of automatic and automated equipment is increasing, but the dominant position still holds the equipment with operation push button, which explains a certain increase in the number of buttons, control stations and various switches. According to leading economists of the country, with time in the structure of Metalworking equipment will be fundamental changes that will give the ability to perform on automated equipment, more than half of all machine operations. This circumstance in the future will slow the pace of growth in the number of control buttons and various switches.

Significantly increasing the applicability of the finite and the limit switches, especially contactless, with an average on a single machine has increased over the past 15 years, more than 13 times. The same trend continues, apparently, in the future.

The analysis and data Table 1 allow in each case to make an informed choice of the type of regression (Tab. 2), which can be used to extrapolate retrospective information on the applicability of low-voltage equipment and its major groups for the foreseeable future. The number of electromagnets and terminals on the perspective adopted unchanged, the prediction of applicability of the finite and limit switches were produced by the logistic curve, and for all other types of ETP and in General for the entire instrument in value terms, the regression equation of the second order. Estimation of the regression coefficients was conducted by the method of least squares.

Regression Equations for predicting the coefficients of $K_{c}^{i}$ applicability

Table 2 of different types of ETP in one cutting machine

\begin{tabular}{|c|c|c|}
\hline Main groups low-voltage equipment & Index $K_{c}^{i}$ & The regression equation \\
\hline Gelatin & $K_{c}^{p m}$ & $K_{c}^{p m}=4,08-0,082 t+0,026 t^{2}$ \\
\hline Breakers & $K_{c}^{\text {va }}$ & $K_{c}^{\text {va }}=1,32+0,083 t+0,002 t^{2}$ \\
\hline Electromagnets & $K_{c}^{e m}$ & $K_{c}^{e m}=0,83=$ const \\
\hline Control buttons & $K_{c}^{k u}$ & $K_{c}^{k u}=4,89+0,136 t+0,0088 t^{2}$ \\
\hline End-travel switches & $K_{c}^{k p}$ & $K_{c}^{k p}=5,94 /\left(1+0,64 e^{-0,233 t}\right)$ \\
\hline Control relay & $K_{c}^{r u}$ & $K_{c}^{r u}=4,1+0,04 t+0,0138 t^{2}$ \\
\hline Switches & $K_{c}^{p k}$ & $K_{c}^{p k}=2,15+0,073 t+0,0091 t^{2}$ \\
\hline Terminals connecting & $K_{c}^{k s}$ & $=68=\operatorname{con} 31$ \\
\hline Fuses & $K_{c}^{p r}$ & $K_{c}^{p r}=7,91 /\left(1+0,29 e^{-0,21 t}\right)$ \\
\hline Connectors & $K_{c}^{r}$ & $=0,67+0,075 t+0,0029 t^{2}$ \\
\hline Proximity switch & $K_{c}^{b v}$ & $K_{c}^{b v}=0,08+0,286 t-0,003 t^{2}$ \\
\hline
\end{tabular}




\section{МЕНЕДЖМЕНТ}

The value of automation, both immediate and in the long term will increase. This is manifested primarily in:

- expanding the scope of its application, in entering into those areas of production that are not yet amenable to cost-effective automation;

- to increase the share of automated equipment in all sectors, in the development of automation comprehensive;

- the transition from more simple forms of automation to a higher, flexible forms, for equipment with numerical control, adaptive control systems that optimize production processes.

The development of automation in these areas would fundamentally change the nature of the proceedings. The practical use of the predictive values of the coefficients of applicability of various types of ETP on the unit of the main technological equipment will allow greater accuracy to determine the prospective value of the industry Park are ETP. And this, in turn, leads to greater validity of promising plans of production of the enterprises of electrotechnical industry.

Conclusions. Products of electrotechnical industry plays a key role in the implementation of electrification, modernization, mechanization, automation and intensification of production processes. Suggestions by the authors on the identification and planning of industry Park ETP on the basis of factors of applicability eliminate labour-intensive method of immediate (direct) Park invoices for electrical automation. The results of these studies can be used by sectoral ministries and large electrical corporations for the establishment of regulatory and reference material for marketing research in determining market (or marketing) characteristics of the product, provide maintenance needs, planning of development indicators of production.

\section{References}

1. Pererva, P. H. (1991). Marketing na promyishlennom predpriyatii [Marketing at the industrial enterprise]. Moscow: NPO «Reklama, informatsiya, marketing» [in Russian].

2. Kobyelyeva, T. O. (2011). Elektrotekhnichna haluz Ukrayiny: suchasnyy stan ta perspektyvy rozvytku [Electrical industry of Ukraine: current state and development prospects]. Visnyk NTU «KhPI» - Bulletin of the NTU "KhPI", 26, 34-43 [in Ukrainian]

3. Pererva, P. G. (1991a). Issledovanie ryinka promyishlennoy produktsii [Market research of industrial products]. Moscow: NPO «Reklama, informatsiya, marketing» [in Russian].

4. Pererva, P. G. (1991b). Upravlenie sbyitom promyishlennoy produktsii $v$ sisteme marketinga [Management of sales of industrial products in the marketing system]. Moscow: NPO «Reklama, informatsiya, marketing» [in Russian].

5. Pererva, P. G., Voronovskii, G. K., Pogorelov, N. I. et al. (2009). Ekonomika $i$ upravleniye innovatsionnoy deyatelnostyu [Economics and management of innovation]. Kharkov: NTU «KhPl» [in Russian].

6. Pererva, P. G. (1991). Upravlenie assortimentom produktsii [Assortment management]. Moscow: NPO «Reklama, informatsiya, marketing» [in Russian].

7. Illyashenko, S. M. (2008). Marketing innovatsiy $i$ innovatsiyi $v$ marketingu [Marketing of innovations and innovations in marketing]. Sumi: VTD «Universitetska kniga» [in Ukrainian].

8. Kosenko, A. P., $\quad$ Kotsiski, D., $\quad$ Maslak, O. I., Pererva, P. G. \& Sakay, D. (2009). Ekonomicheskaya otsenka innovatsionnogo potentsiala [Economic evaluation of innovative potential]. Kharkov-Mishkolts: NTU „HPI”, Mishkolts.tehn.un-t. [in Russian].

9. Poberezhna, N. M. \& Pererva, P. G. (2012). Viznachennya efektivnosti vikoristannya virobnichogo

\section{Література}

1. Перерва, П. Г. Маркетинг на промышленном предприятии / П. Г. Перерва. - М. : НПО «Реклама, информация, маркетинг», 1991. - 80 с.

2. Кобєлєва, Т. О. Електротехнічна галузь України: сучасний стан та перспективи розвитку // Т. О. Кобєлєва // Вісник НТУ «ХП|». - 2011. - № 26. - С. 34-43.

3. Перерва, П. Г. Исследование рынка промышленной продукции / П. Г. Перерва. - М. : НПО «Реклама, информация, маркетинг», 1991. - 96 с.

4. Перерва, П. Г. Управление сбытом промышленной продукции в системе маркетинга / П. Г. Перерва. - М. : НПО «Реклама, информация, маркетинг», 1991.- 93 с.

5. Экономика и управление инновационной деятельностью / под ред. проф. Перервы П. Г., проф. Вороновского Г. К., проф. Меховича С. А., проф. Погорелова Н. И. - Харьков : НТУ «ХПИ», 2009. - 1203 c.

6. Перерва, П. Г. Управление ассортиментом продукции / П. Г. Перерва. - М. : НПО «Реклама информация, маркетинг», 1991. - 80 с.

7. Ілляшенко, С.М.Маркетинг інновацій і інновації в маркетингу: монографрія / за ред. С. М. Ілляшенка. Суми : ВТД «Університетська книга», 2008. - 615 с.

8. Косенко, А. П. Экономическая оценка инновационного потенциала: монографрия / А. П. Косенко, Д. Коциски, О. И. Маслак, П. Г. Перерва, Д. Сакай; под ред. проф. Перервы П. и проф. Д. Коциски Харьков-Мишкольц : НТУ „ХПИ”, Мишкольц.техн.ун-т, 2009. - $170 \mathrm{c}$.

9. Побережна, Н. М. Визначення ефективності використання виробничого потенціалу машинобудівного підприємства / П. Г. Перерва, Н.М. Побережна // Маркетинг і менеджмент інновацій. 2012. - №2. - C. 191-198. 


\section{МЕНЕДЖМЕНТ}

potentsialu mashinobudivnogo pidpriemstva [Determination of
the efficiency of use of industrial potential of machine-building
enterprise]. Marketing i menedzhment innovatsiy - Marketing
and innovation management, 2, 191-198 [in Ukrainian].
10. Plotnikov, V. A. (2010). Gosudarstvo i ryinok:
mehanizmyi i metodyi regulirovaniya v usloviyah preodoleniya
krizisa [State and market: regulation mechanisms and
methods under the conditions of overcoming of crisis]. (Vol. 2),
(pp. 254-264). Saint Petersburg: Astérion [in Russian].
11. Pererva, P. G. (1991). Prakticheskiy marketing
[Practical marketing]. Spravochnyk menedzhera
prombshlennoho predpryiatyia - Directory of the manager of
an industrial enterprise (Vol. 1). Moscow: NPO «Reklama,
informatsiya, marketing» [in Russian].
12. Kosenko, A. P., Kobielieva, T. O. \& Tkachova, N. P.
(2017). The definition of industry park electrical products.
Naukoviy visnik Polissya - Scientific bulletin of Polissia, 3(10),
43-50 [in English].

10.Плотников, В.А. Государство и рынок: механизмы и методы регулирования в условиях преодоления кризиса: колл. монография.- СПб.: Астерион, 2010.- Т. 2.- п. 6.2.- С. 254-264.

11. Перерва, П. Г. Практический маркетинг. Вып. 2. Маркетинг на промышленном предприятии / П. Г. Перерва. - Москва : НПО "РИМ", 1991. - 79 с.

12. Kosenko, A. P. The definition of industry park electrical products / A. P. Kosenko, T. O. Kobielieva, N. P. Tkachova // Науковий вісник Полісся. - 2017. - № 3 (10). - C. 43-50.

\section{Бібліографічний опис для цитування:}

Kosenko, O.P. / Forecasting industry park electrical products / O. P. Kosenko, Т. О. Kobielieva, N. P. Tkachova // Науковий вісник Полісся. - 2017. - № 4 (12). Ч. 2. - С. 106-111. 